DOI: https://doi.org/10.46879/ukroj.3.2021.09-21

удк: $615.849+616-71 / 78$

Контроль спектральних характеристик медичного прискорювача на основі порівняння масових коефіцієнтів ослаблення різних матеріалів

Чернявський I.Ю.' ${ }^{1}$, ORCID: 0000-0002-2785-0617, e-mail: chern.igor.71@gmail.com Старенький В.П. ${ }^{1}$, ORCID:0000-0002-6600-3381, e-mail: starenkiy.victor@gmail.com Макієнко A.C.1, ${ }^{1}$, ORCID: 0000-0001-6021-7429, e-mail: makienko.alla@gmail.com

Авер'янова Л.0. ${ }^{3}$, ORCID: 0000-0003-0803-7222, e-mail: lilya.averyanova@nure.ua

Петриченко 0.0.4, ORCID: 0000-0003-3226-2008, e-mail: medlu@ukr.net

Поплавець C.I. ${ }^{5}$, ORCID: 0000-0001-6874-1938, e-mail: serg751505@gmail.com

'Державна установа «lнститут медичної радіології та онкології ім. С.П. Григор'єва Національної академії медичних наук України», Харків, Україна

${ }^{2}$ Харківський радіотехнічний коледж

Міністерства освіти і науки України, Харків, Україна

${ }^{3}$ Харківський національний університет радіоелектроніки

Міністерства освіти і науки України, Харків, Україна

${ }^{4}$ Національна академія медичних наук України, Київ, Україна

${ }^{5}$ Харківський національний університет Повітряних Сил ім. Івана Кожедуба

Міністерства оборони України, Харків, Україна

\title{
Control of spectral characteristics of the medical accelerator on the basis of comparison of mass weaking coefficients of different materials Cherniavskiy I.Yu. ${ }^{1}$, ORSID: 0000-0002-2785-0617, e-mail: chern.igor.71@gmail.com Starenky V.P. ${ }^{1}$, ORCID: 0000-0002-6600-3381, e-mail: starenkiy.victor@gmail.com Makienko A.S., 2, ORCID: 0000-0001-6021-7429, e-mail: makienko.alla@gmail.com Averyanova L.O. ${ }^{3}$, ORCID: 0000-0003-0803-7222, e-mail: lilya.averyanova@nure.ua Petrychenko 0.0.4, ORCID: 0000-0003-3226-2008, e-mail: medlu@ukr.net Poplavetz S.I. ${ }^{5}$, ORCID: 0000-0001-6874-1938, e-mail: serg751505@gmail.com \\ ${ }^{1}$ State Organization «Grigoriev Institute for Medical Radiology and Oncology of the National Academy of Medical Sciences of Ukraine», Kharkiv, Ukraine \\ ${ }^{2}$ Kharkiv Radioengineering College of the Ministry of Education and Science of Ukraine, Kharkiv, Ukraine ${ }^{3}$ Kharkiv National University of Radio Electronics of the Ministry of Education and Science of Ukraine, Kharkiv, Ukraine ${ }^{4}$ National Academy of Medical Sciences of Ukraine, Kyiv, Ukraine 5Ivan Kozhedub Kharkiv National University of the Air Force of the Ministry of Defense of Ukraine, Kharkiv, Ukraine
}

Ключові слова:

спектральна характеристика, лінійний прискорювач, гальмівне випромінювання, масовий коефіцієнт ослаблення.

\section{Для кореспонденції:}

Старенький Віктор Петрович

Державна установа «Інститут медичної радіології та онкології ім. С. П. Григор'єва Національної академії медичних наук України», відділення радіаційної онкології;

вул. Пушкінська, буд. 82, м. Харків, Україна, 61024

e-mail: starenkiy.victor@gmail.com

() Чернявський І.Ю., Старенький В.П., Макієнко А.С., Авер'янова Л.О.,

Петриченко О.О., Поплавець С.І., 2021
PE3ЮME

Актуальність. Гарантія радіаційного захисту пацієнтів під час лікування із застосуванням лінійних прискорювачів електронів, базується на забезпеченні сталості параметрів обладнання, встановлених під час введення в експлуатацію. Тому вивчення можливості оперативного оцінювання стабільності спектральних характеристик сформованого гальмівного випромінювання $€$ досить актуальною задачею поряд із процедурами контролю стандартних дозиметричних параметрів. Мова перш за все йде про визначення середньої зваженої енергії гальмівного випромінювання, яка дає об'єктивну оцінку сталості всього хвильового тракту прискорювача. Однак, спеціального діагностичного обладнання для визначення цього параметра не існує. У той же час дані літератури свідчать про зростаючий інтерес до застосування CdTe-датчиків для аналізу високоенергетичного випромінювання, в тому числі і у медичних прискорювачах.

Мета роботи - розробити та опробувати спеціальну діагностичну апаратуру на основі напівпровідникових CdTe-датчиків, яка б реалізовувала оцінку середньої зваженої енергії гальмівного випромінювання медичного прискорювача $6 \mathrm{MeB}$, шляхом порівняння масових коефіцієнтів ослаблення у свинці та алюмінії.

Матеріали та методи. У роботі проведена експериментальна оцінка спектральних характеристик медичного прискорювача Varian Clinac 600C (США) відділення радіаційної онкології Державної установи «Інститут медичної радіології та онкології ім. С.П. Григор'єва Національної академії медичних наук України» шляхом визначення середньої зваженої енергії гальмівного випромінювання. Визначення серед- 
ньої зваженої енергії гальмівного випромінювання прискорювача здійснювалось на основі порівняння двох масових коефіцієнтів ослаблення випромінювання матеріалами з суттєво різними атомними номерами - $\mathrm{Al}$ та $\mathrm{Pb}$. Оцінка масових коефріцієнтів ослаблення здійснювалась на основі вимірювання середніх амплітуд сигналів CdTе-датчика, який працював у імпульсному режимі сумісно з 16-розрядним аналоговим цифровим перетворювачем (АЦП). Імпульси гальмівного випромінювання від лінійного прискорювача були зареєстровані піковим детектором протягом 10 секунд вимірювання апаратно-програмним комплексом при 400 моніторних одиницях $\mathrm{CdTe-датчиком} \mathrm{з} \mathrm{алюмінієвим} \mathrm{та} \mathrm{свинцевим} \mathrm{поглиначем.} \mathrm{Дослідження} \mathrm{проводилось} \mathrm{на}$ відстані «джерело-поверхня» 100 см з площею поля опромінення 20×20 см. Досліджено спектральний профіль енергії сформованого поля гальмівного випромінювання. Результати та їх обговорення. Проведена апробація розробленої апаратури 3 CdTe-датчиком, яка була створена з урахуванням як енергетичної чутливості самого датчика, так i зі спектрально-часовими характеристиками імпульсного випромінювання прискорювача. Експериментально підтверджений підхід до оцінки середньої зваженої енергії гальмівного випромінювання лінійного прискорювача електронів, який базується на залежності ослаблення випромінювання шаром поглинача від енергії випромінювання. Отримана теоретична залежність середнього значення зваженої енергії гальмівного випромінювання лінійного прискорювача від відношення масових коефіцієнтів ослаблення свинцю та алюмінію. Енергетичному діапазону від 0,1 до 6 МеВ відповідає відношення масових коефіцієнтів поглинання свинцю до алюмінію, які змінюються нелінійно від 33,8 до 1,639. Середній зваженій енергії лінійного прискорювача у 0,8 МеВ відповідає відношення масових коефріцієнтів близько 1,23 для даних матеріалів. Оцінена абсолютна похибка (від встановленого значення під час введення в експлуатацію лінійного прискорювача) визначеної середньої зваженої енергії гальмівного випромінювання, яка не перевищує $12 \%(0,72 \mathrm{MeB})$, що відповідає відношенню масових коефіцієнтів ослаблення - 1,340. Висновки. Обґрунтована та практично реалізована спеціальна діагностична апаратура реєстрації спектральних характеристик лінійного прискорювача Varian Clinac 600C (США) на основі напівпровідникових CdTe-датчиків, які сумісно 3 16-розрядним АЦП дозволяють оцінити середню зважену енергію гальмівного випромінювання, шляхом порівняння масових коефріцієнтів ослаблення у $\mathrm{Al} \mathrm{Ta} \mathrm{Pb}$. Оцінка масових коефіцієнтів ослаблення здійснюється на основі вимірювання середніх амплітуд імпульсів CdTe-датчиків, працюючих у імпульсному режимі.

\section{Для цитування:}

Чернявський І.Ю., Старенький В.П., Макієнко А.С., Авер'янова Л.О., Петриченко О.О., Поплавець С.І. Контроль спектральних характеристик медичного прискорювача на основі порівняння масових коефріцієнтів ослаблення різних матеріалів. Український радіологічний та онкологічний журнал. 2021. Т. 29. № 3. С. 9-21. DOI: https://doi.org/10.46879/ukroj.3.2021.09-21

\section{Key words:}

spectrum characteristics, linear accelerator, bremsstrahlung, mass attenuation coefficient.

\section{For correspondence:}

\section{Starenky Viktor Petrovych}

State Organization «Grigoriev Institute for Medical Radiology and Oncology of the National Academy of Medical Sciences of Ukraine», Radiation Oncology Department; 82, Pushkinska Str., Kharkiv, Ukraine, 61024;

e-mail: starenkiy.victor@gmail.com

(c) Cherniavskiy I.Yu., Starenky V.P., Makienko A.S., Averyanova L.O. Petrychenko O.O., Poplavets S.I., 2021

\section{ABSTRACT}

Background. Radiation protection of patients undergoing radiation therapy using linear electron accelerators is based on ensuring the constancy of the equipment parameters set during commissioning. Therefore, studying the possibility of operational assessment of the spectrum characteristics consistency of the generated bremsstrahlung is a priority along with standard dosimetric parameter control procedures. Primarily, this refers to specifying the average measured energy of bremsstrahlung which provides an impartial assessment of the constancy of the whole wave path of the accelerator. However, there is no special diagnostic equipment to determine this parameter. At the same time, the literature data represent a growing interest in the use of CdTe sensors for the analysis of high-energy radiation, including the ones in medical accelerators.

Purpose - developing and testing special diagnostic equipment based on semiconductor CdTe sensors, which would implement the assessment of the average measured energy of bremsstrahlung of the medical accelerator $6 \mathrm{MeV}$ via comparing the mass attenuation coefficients in lead and aluminum.

Materials and Methods. The paper deals with experimental evaluation of the Varian Clinac $600 \mathrm{C}$ linear accelerator (USA) spectrum characteristics carried out at Radiation Oncology Department of State Organization «Grigoriev Institute for Medical Radiology and Oncology of the National Academy of Medical Sciences of Ukraine» via determining the average measured energy of bremsstrahlung. The assessment of the average measured energy of the bremsstrahlung of the accelerator was performed based on comparing two mass attenuation coefficients of radiation with materials having significantly different atomic numbers, i.e. $\mathrm{Al}$ and $\mathrm{Pb}$. The assessment of the mass attenuation coefficients was performed on the basis of measuring the average amplitudes of CdTe signals of the sensor, operating in the pulse mode in conjunction with a 16-bit ADC. Pulses of bremsstrahlung from the linear accelerator were recorded by a peak detector for 10 seconds of measurement by the hardware-software complex at 400 monitor units by CdTe sensor with aluminum and lead absorber. The study was performed at a distance of «source-surface» $100 \mathrm{~cm}$ with an area of the irradiation field of $20 \times 20 \mathrm{~cm}$. The spectral energy profile of the generated field of bremsstrahlung was studied. 
Results. The developed equipment was tested by CdTe sensor, which was created taking into account the energy sensitivity of the sensor itself as well as the spectraltemporal characteristics of the pulsed radiation of the accelerator. The approach dealing with assessing the average measured energy of bremsstrahlung of the linear electron accelerator, based on the dependence of the attenuation of radiation by the absorber layer on the radiation energy, has been experimentally confirmed. The theoretical dependence of the average measured energy of bremsstrahlung of the linear accelerator on the ratio of the mass attenuation coefficients of lead and aluminum has been obtained. The energy range from 0.1 to $6 \mathrm{MeV}$ corresponds to the ratio of mass absorption coefficients of lead to aluminum, varying nonlinearly from 33.8 to 1.639 . The average measured energy of the linear accelerator of $0.8 \mathrm{MeV}$ corresponds to a mass coefficient ratio of about 1.23 for these materials. The assessed absolute error (from the set value during commissioning the linear accelerator) of the specified measured average energy of bremsstrahlung is up to $12.5 \%(0.72 \mathrm{MeV})$, corresponding to the ratio of mass attenuation coefficients -1.340 .

Conclusions. The special diagnostic equipment for recording the spectrum characteristics of the Varian Clinac $600 \mathrm{C}$ linear accelerator (USA) based on semiconductor CdTe sensors, which along with 16-bit ADC make it possible to estimate the average measured energy of bremsstrahlung via comparing mass attenuation coefficients in $\mathrm{Al}$ and $\mathrm{Pb}$ has been substantiated and reduced to practice. The assessment of mass attenuation coefficients is carried out based on measuring the average amplitudes of pulses of $\mathrm{CdTe}$ sensors operating in a pulse mode.

For citation:

Cherniavskiy IYu, Starenky VP, Makienko AS, Averyanova LO, Petrychenko OO, Poplavets SI. Control of medical accelerator spectrum characteristics based on comparing the mass attenuation coefficient of different materials. Ukrainian journal of radiology and oncology. 2021;29(3):9-21. DOI: https://doi.org/10.46879/ukroj.3.2021.9-21

\section{Зв'язок роботи 3 науковими програмами,} планами і темами

\section{Relationship with academic programs,} plans and themes
Робота є фррагментом планової науково-дослідної роботи Державної установи «Інститут медичної радіології та онкології ім. С.П. Григор'єва Національної академії медичних наук України» «Оптимізація топометричної підготовки хворих на рак голови та шиї». Номер державної реєстрації: 0119U103013, прикладна, термін виконання: 01.2020-12.2022 рр., керівники головний науковий співробітник групи променевої терапії відділу радіології, завідувач відділення радіаційної онкології, доктор медичних наук, професор Старенький В.П.; головний науковий співробітник групи променевої терапії відділу радіології, доктор медичних наук, професор Сухіна О.М.
The paper is a fragment of the planned research project of State Organization «Grigoriev Institute for Medical Radiology and Oncology of the National Academy of Medical Sciences of Ukraine» which is "Optimize topometric preparation for radiation therapy in patients with head and neck cancer». State registration number: 0119U103013, applied, period for performance: 01.202012.2022, led by Chief Researcher of Radiation Therapy Group of Radiology Department, Head of Radiation Oncology Department, Doctor of Medical Sciences, Professor V.P. Starenky; Chief Researcher of Radiation Therapy Group of Radiology Department, Doctor of Medical Sciences, Professor O.M. Sukhina.

\section{ВСТУП}

Метою контролю якості променевої терапії із застосуванням лінійних прискорювачів електронів $є$ забезпечення сталості параметрів обладнання, встановлених під час введення в експлуатацію, що безумовно є ключовим елементом радіаційного захисту пацієнтів [1]. Багаторічний досвід експлуатації та технічного обслуговування лінійного прискорювача Varian Clinac 600C у відділенні променевої терапії Державної установи «Інститут медичної радіології та онкології ім. С.П. Григор'єва Національної академії медичних наук України» за умов щоденного інтенсивного навантаження на радіотерапевтичну систему (понад 40 пацієнтів), вказує, що неточність відтворення дозового профрілю в полі опромінення може бути зумовлена не тільки нестабільністю інтенсивності сформованого потоку, але і спектральною неоднорідністю енергії фотонів гальмівного випромінювання. За рахунок зміни товщини поглинаючого матеріалу вирівнюючих фрільтрів (Pb, W, Fe, Al та ін.), зменшують інтенсивність фротонного випромінювання у напрямку генерації пучка до середнього рівня [2, 3]. У результаті спектр сформованого випромінювання (рис. 1) у фрокусі поля

\section{INTRODUCTION}

Radiation therapy quality control with the use of linear electron accelerators is aimed at ensuring the constancy of the equipment parameters set during commissioning, which is certainly a key element of radiation protection of patients [1]. Many years of experience in operation and maintenance of the Varian Clinac 600C linear accelerator (USA) at Radiation Therapy Department of State Organization "Grigoriev Institute for Medical Radiology and Oncology of the National Academy of Medical Sciences of Ukraine» under daily intensive load on the radiotherapy system (more than 40 patients), indicates that the inaccuracy of reproducing the dose profile in the irradiation area can be determined not only by the instability of the generated flow intensity, but also by spectral inhomogeneity of bremsstrahlung photon energy. By changing the thickness of the absorbing material of the flattening filters $(\mathrm{Pb}, \mathrm{W}, \mathrm{Fe}$, $\mathrm{Al}$, etc.), they reduce the intensity of photon radiation in the direction of beam generation to the average level [2, 3]. As a result, the spectrum of the generated radiation (Fig. 1) in the focus of the field also has the highest intensity with some average value of bremsstrahlung energy. 
також має найбільшу інтенсивність з деяким середнім значенням енергії гальмівного випромінювання.

Даний середній рівень енергії також може змінюватись з часом експлуатації генеруючої системи та через нестабільність роботи системи охолодження мішені лінійного прискорювача, що змушує оперативно контролювати відхилення спектральних характеристик гальмівного випромінювання від встановлених норм. У цих випадках доцільно контролювати не стільки сам енергетичний розподіл випромінювання (рис. 1), а саме середню зважену енергію гальмівного випромінювання.
This average energy level can also change in the course of the operating time of the generating system and due to instability of the cooling system of the target of the linear accelerator, forcing it to quickly control the deviation of the spectrum characteristics of bremsstrahlung from the established normal range. In these cases, it is advisable to control not so much the energy distribution of radiation (Fig. 1), but the average measured energy of bremsstrahlung.

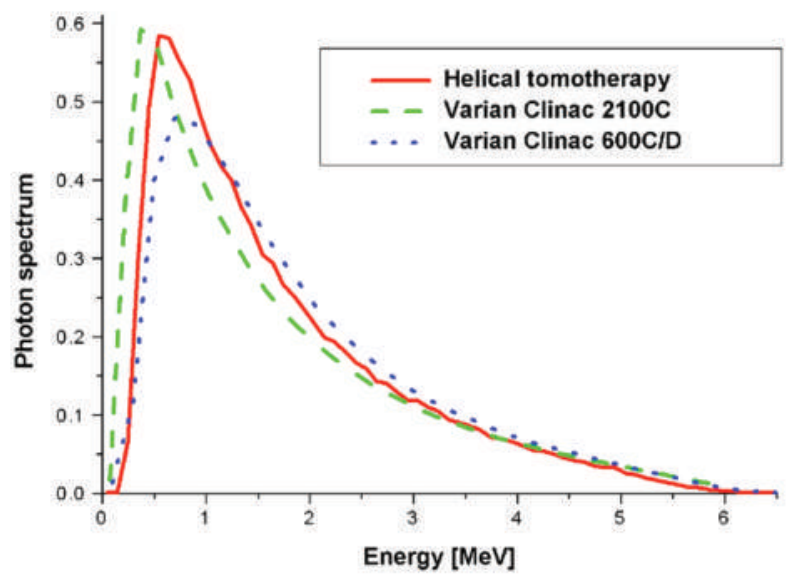

Рис. 1. Спектральний розподіл енергії фотонного випромінювання лінійних прискорювачів [3]

Fig. 1. Spectral distribution of photon radiation energy of linear accelerators [3]

Непрямий контроль спектра випромінювання для планувальної системи здійснюється шляхом попередньої оцінки відсоткової глибинної дози - розподіл дози вздовж центральної осі гальмівного випромінювання [4]. Це налаштування зараз здійснюється у результаті дозиметрії у водному франтомі, іє складною і високовартісною процедурою 3 використанням високоточних клінічних дозиметрів UNIDOS у комплексі з іонізаційною камерою. У той же час існуюча у терапевтичних прискорювачах подвійна трансмісійна іонізаційна камера $[3,5]$, дозволяє лише оперативно вимикати прискорювач при зміні рівня запланованої у планувальній системі енергії. Тому об'єктивну інформацію щодо якості генерованого спектра гальмівного випромінювання медичного лінійного прискорювача можуть дати тільки спеціально розроблені діагностичні системи, які призначені для атестації (верифікації) режимів роботи прискорювача, для контролю стабільності параметрів випромінювання [6, 7].

Таким чином, вивчення можливості оперативного оцінювання стабільності спектральних характеристик сформованого гальмівного випромінювання $€$ досить актуальною науковою і прикладною задачею.

Мета роботи - розробка та опробування спеціальної діагностичної апаратури на основі напівпровідникових $\mathrm{CdTe}$-датчиків, яка б реалізовувала оцінку середньої зваженої енергії гальмівного випромінювання медичного прискорювача $6 \mathrm{MeB}$, шляхом порівняння масових коефіцієнтів ослаблення у свинці та алюмінії.

\section{МАТЕРІАЛИ ТА МЕТОДИ ДОСЛІДЖЕННЯ}

\section{Аналіз літературних джерел \\ і постановка проблеми}

У науковій літературі існує низка досліджень щодо оцінки спектральних характеристик лінійних прискорювачів. У роботі [8] досліджено енергетичний спектр
Indirect control of the radiation spectrum for the planning system is carried out by preliminary assessment of the percentage depth dose - dose distribution along the central axis of bremsstrahlung [4]. This setup is now performed as a result of water phantom dosimetry, which is a complex and costly procedure using high-precision UNIDOS clinical dosimeters in combination with an ionization chamber. At the same time, the existing dual acceleration ionization chamber in therapeutic accelerators $[3,5]$ makes it possible only to quickly turn off the accelerator when the level of energy planned in the planning system changes. Therefore, objective information about the quality of generated bremsstrahlung spectrum of a medical linear accelerator can be provided only by specially developed diagnostic systems that are designed to certify (verify) the modes of the accelerator to control radiation parameter stability $[6,7]$.

Thus, studying the possibility of operative assessment of the stability of the spectrum characteristics of the generated bremsstrahlung is a rather important scientific and applied task.

Purpose - developing and testing special diagnostic equipment based on semiconductor CdTe sensors, which would implement the assessment of the average measured energy of bremsstrahlung of the medical accelerator $6 \mathrm{MeV}$ via comparing the mass attenuation coefficients in lead and aluminum.

\section{MATERIALS AND METHODS}

\section{Analysis of literary sources and problem statement}

There are a number of studies in the literature dealing with assessing the spectrum characteristics of linear accelerators. The paper [8] is focused on studying the 
лінійного прискорювача $6 \mathrm{MeB}$ за допомогою пристрою спектроскопії комптонівського розсіювання 3 використанням імпульсного детектора 3 германію (HPGe). Для точного визначення спектра виникає складність у оптимізації налаштування спектрометричного детектора та в цілому спектрометричного каналу.

Метод вимірювання середньої енергії квантів прискорювача ЛИУ-30, заснований на використанні детекторів 3 лінійними спектральними характеристиками викладено у роботі [9]. В роботі [10] описаний метод вимірювання середньої енергії квантів гальмівного випромінювання прискорювача на основі використання конвертора, який включає у себе сцинтилятор та встановлений перед ним комбінований шар речовини. Реалізована схема фрізичного підсумовування інформації, у якій здійснюється реєстрація одним сцинтиляційним детектором розсіяних конвертором квантів, розповсюджених у повітрі, і світлового спалаху від сцинтилятора конвертора, переданого по волоконнооптичній лінії зв'язку.

У роботі [11] проведено діагностування електронних пучків прискорювача ЛИУ-10М, ЛИУ-30 за спектральночасовими характеристиками, які генеруються гальмівним випромінюванням у діапазоні до 60 МеВ. Автори використовують активаційний метод [12] та метод поглинаючих фрільтрів з використанням фільтрів з різних матеріалів.

У [13] проведено моделювання процедури вимірювання енергії немонохроматичного пучка електронів методом ослаблення гальмівного випромінювання поглинаючим бар'єром. Виконано порівняння значення енергії, яка вимірюється даним методом, із середньою енергією і енергією максимуму спектра електронного пучка. У дослідженні для виявлення середньої енергії даний підхід реалізується тільки на легких матеріалах, який потребує нарощування товщини поглинаючої речовини для побудови графрічної залежності лінійного коефіцієнта ослаблення від товщини матеріалу, тому не $є$ оперативним та надійним.

У той же час відомо, що у поглиначі з алюмінію у широкому інтервалі енергій фотонів 50 кеB<hv<15 MeB домінує комптон-ефект. У поглиначі зі свинцю фотоефект же $є$ домінуючим до енергії 0,5 MеВ, а при hv>5 МеB основну роль грає процес утворення пар. Поглинання фоотонів за рахунок фотоефекту у алюмінію дуже мале при заданих енергіях гальмівного випромінювання прискорювача. Коефіцієнт масового ослаблення для усіх елементів, за виключенням водню, має різкий підйом у ділянці низьких енергій, який вказує, що у цій ділянці домінуючим процесом взаємодії $€$ фотоелектричне поглинання, а розташування даного підйому значно залежить від атомного номера речовини [14]. В алюмінії він спостерігається при енергії приблизно 20 МеВ, у міді - при 8 МеВ та у свинцю - 3,4 МеВ.

Таким чином, у зв'язку з такою різницею в зазначених ефектах взаємодії випромінювання 3 легким матеріалом - алюмінієм (Al) та з важким - свинцем (Pb), з'являється теоретична можливість визначити середню зважену енергію гальмівного випромінювання шляхом порівняння двох масових коефіцієнтів ослаблення цих матеріалів $\mu_{m}^{P_{b}} / \mu_{m}^{A l}$. У роботах $[15,16]$ було підтверджено, що крива пропускання матеріалів з високим порядковим номером Z впливає на точність відновлення спектра більше, ніж з низьким Z. Однак це питання недостатньо вивчено як у теоретичному, так і в практичному плані. Для реалізації даного підходу виникає energy spectrum of $6 \mathrm{MeV}$ linear accelerator by means of Compton scattering spectroscopy device using a pulsed germanium detector (HPGe). To accurately determine the spectrum, there is a difficulty in optimizing the settings of the spectrometric detector and the spectrometric channel as a whole.

The method of measuring the average energy of the quanta of LIU-30 accelerator based on the use of detectors with linear spectrum characteristics is described in [9]. The paper [10] describes a method for measuring the average energy of bremsstrahlung quanta of the accelerator based on the use of a converter, which includes a scintillator and a combined layer of matter installed in front of it. The scheme of physical summation of information, in which the registration of converter-scattered quanta, spread over the air and a flash of light from the converter scintillator transmitted over the fiber-optic communication line, is carried out via one scintillation detector, has been implemented.

In [11], the electron beams of LIU-10M and LIU-30 accelerators were diagnosed by spectral-temporal characteristics generated by bremsstrahlung in the range up to $60 \mathrm{MeV}$. The authors use the activation method [12] and the method of absorbing filters involving the filters made of different materials.

In [13], the procedure for measuring the energy of a nonmonochromatic electron beam by the method of attenuation of bremsstrahlung by an absorption barrier was performed. The comparison of the value of energy measured by this method with the average energy and the maximum energy of the electron beam spectrum is carried out. In the paper, in order to detect the average energy, this approach is being implemented only on light materials, which requires increasing the thickness of the absorbent to build a graphical dependence of the linear attenuation coefficient on the thickness of the material, so it is not fast and reliable.

At the same time, it is known that the Compton effect dominates in the aluminum absorber in a wide range of photon energies of $50 \mathrm{keV}<\mathrm{hv}<15 \mathrm{MeV}$. In a lead absorber, the photoeffect is dominant to the energy of $0.5 \mathrm{MeV}$, and at hv> $5 \mathrm{MeV}$ the main role is played by the process of vapor formation. The absorption of photons due to the photoeffect in aluminum is very small at given energies of the accelerator bremsstrahlung. The mass attenuation coefficient for all elements, except hydrogen, has a sharp rise in the low-energy region, which indicates that the dominant interaction process in this region is photoelectric absorption, and the location of this rise depends on the atomic number of the substance [14]. In aluminum it is observed at the energy of about $20 \mathrm{MeV}$, in copper at $8 \mathrm{MeV}$ and in lead-3.4 MeV.

Thus, due to such difference in these effects of interaction of radiation with light material - aluminum (Al) AND with heavy one - lead $(\mathrm{Pb})$, there is a theoretical possibility to assess the average measured energy of bremsstrahlung by comparing two mass attenuation coefficients of these materials $\mu_{m}^{P_{b}} / \mu_{m}^{A l}$. In $[15,16]$, it has been confirmed that the material transmission curve with a high sequence number $Z$ affects the accuracy of spectrum recovery more than with a low $Z$. However, this issue is insufficiently studied, both theoretically and practically. To implement this approach, there is an urgent need to have special diagnostic equipment designed in accordance with the spectral-temporal 
Таблиця 1. Теоретична залежність середньої зваженої енергії гальмівного випромінювання (МеВ) лінійного прискорювача від відношення масових коефіцієнтів ослаблення свинцю $\left(\rho=11,34 \mathrm{r} / \mathrm{cm}^{3}\right)$ та алюмінію $\left(\rho=2,70 \mathrm{r} / \mathrm{cm}^{3}\right)$

Table 1. Theoretical dependence of the average weighted braking energy $(\mathrm{MeV})$ of a linear accelerator on the ratio of the mass attenuation coefficients of lead $\left(\rho=11.34 \mathrm{~g} / \mathrm{cm}^{3}\right)$ and aluminum $\left(\rho=2.70 \mathrm{~g} / \mathrm{cm}^{3}\right)$

\begin{tabular}{|c|c|c|c|}
\hline$E_{v}, M e B$ & $\begin{array}{ll}\mu_{m}^{P_{b}} & \mathrm{CM}^{2} / \Gamma \\
\mathrm{cm}^{2} / \mathrm{g}\end{array}$ & $\begin{array}{lll}\mu_{m}^{A l} \quad \mathrm{~cm}^{2} / r \\
\mathrm{~cm}^{2} / \mathrm{g}\end{array}$ & $\mu_{m}^{P_{b}} / \mu_{m}^{A l}$ \\
\hline 0,1 & 5,32 & 0,157 & 33,88 \\
\hline 0,145 & 2,17 & 0,134 & 16,19 \\
\hline 0,15 & 1,92 & 0,132 & 12,8 \\
\hline 0,2 & 0,242 & 0,119 & 7,91 \\
\hline 0,279 & 0,410 & 0,106 & 3,86 \\
\hline 0,5 & 0,150 & 0,0839 & 1,807 \\
\hline 0,6 & 0,117 & 0,0774 & 1,511 \\
\hline 0,662 & 0,104 & 0,0743 & 1,399 \\
\hline 0,8 & 0,0840 & 0,0681 & 1,233 \\
\hline 1,0 & 0,0680 & 0,0612 & 1,111 \\
\hline 1,25 & 0,0580 & 0,0550 & 1,054 \\
\hline 1,5 & 0,0509 & 0,0500 & 1,018 \\
\hline 2,0 & 0,0448 & 0,0431 & 1,039 \\
\hline 2,75 & 0,0420 & 0,0368 & 1,141 \\
\hline 3,0 & 0,0413 & 0,0355 & 1,163 \\
\hline 4,0 & 0,0416 & 0,0310 & 1,341 \\
\hline 5,0 & 0,0424 & 0,0283 & 1,498 \\
\hline 6,0 & 0,0459 & 0,0266 & 1,639 \\
\hline
\end{tabular}

гостра необхідність мати спеціальну діагностичну апаратуру, розроблену за спектрально-часовими характеристиками високоінтенсивного імпульсного гальмівного випромінювання прискорювача, яка спроможна вимірювати середню зважену енергію гальмівного випромінювання прискорювача.

Залежність масових коефріцієнтів ослаблення від енергії гамма-випромінювання для різних матеріалів відома в літературі 3 похибкою приблизно 1-2\%. Відношення масових коефіцієнтів ослаблення $\mu_{m}^{p_{p}} / \mu_{m}^{A l}$ можна виміряти з великою точністю [14], а похибка визначення енергії буде залежати від величини похідної $d \mu_{m} / d E_{\gamma}$.

У таблиці 1 представлені результати оцінки відношення масових коефіцієнтів $\mu_{m}^{P_{b}} / \mu_{m}^{A l}$ свинцю та алюмінію для спектра гальмівного випромінювання лінійного прискорювача Varian Clinac 600C [3].

Енергетичному діапазону гальмівного випромінювання лінійного прискорювача від 0,1 до 6 МеВ відповідає відношення масових коефіцієнтів ослаблення свинцю до алюмінію, які змінюються нелінійно від 33,8 до 1,639. Для середньої зваженої енергії лінійного прискорювача у 0,8 МеВ відношення масових коефіцієнтів має складати близько 1,233 для даних матеріалів.

Але на практиці істотним джерелом похибок при визначенні середньої зваженої енергії гальмівного випромінювання за $\mu_{m}^{p_{b}} / \mu_{m}^{A l}$ може стати недостатньо хороша «геометрія» експерименту, при якому у датчик може потрапляти частина розсіяного випромінювання. щоб зменшити можливість його попадання необхідно або використовувати по можливості вузький пучок гальмівного випромінювання, (перед датчиком використовувати коліматор), або використовувати датчик малих розмірів. При великій товщині шару поглинача, characteristics of high-intensity pulsed bremsstrahlung of the accelerator which is able to measure the average measured energy of accelerator bremsstrahlung.

The dependence of the mass attenuation coefficients on gamma radiation energy for different materials is known in the literature with an error of about $1-2 \%$. The ratio of mass attenuation coefficients $\mu_{m}^{P_{b}} / \mu_{m}^{A l}$ can be measured with a great accuracy [14], while the error in determining the energy will depend on the value of the derivative $d \mu_{m} / d E_{\gamma}$.

Table 1 represents the outcomes of assessing the ratio of the mass coefficients $\mu_{m}^{P_{b}} / \mu_{m}^{A l}$ of lead and aluminum for the bremsstrahlung spectrum of the Varian Clinac 600C linear accelerator (USA) [3].

The energy range of bremsstrahlung of the linear accelerator from 0.1 to $6 \mathrm{MeV}$ corresponds to the ratio of the mass attenuation coefficients of lead to aluminum, which varies nonlinearly from 33.8 to 1.639 . For the average measured energy of the linear accelerator of $0.8 \mathrm{MeV}$, the ratio of the mass coefficients should be about 1.233 for these materials.

However, in effect, a significant source of errors in determining the average measured energy of bremsstrahlung $\mu_{m}^{P_{b}} / \mu_{m}^{A l}$ can be the experiment "geometry» which is not quite good, in which the sensor can get part of the scattered radiation. To reduce the possibility of its impact, it is necessary to either use as narrow beam of bremsstrahlung as possible (use a collimator before the sensor), or use a small sensor. With a large thickness of the absorber layer, due to repeated scattering of radiation, soft radiation occurs. This scattered radiation can enter the sensor even with good collimation. That is why the thickness of the absorber layer should not exceed the average free path length of bremsstrah- 
за рахунок багаторазового розсіювання випромінювання, виникає м'яке випромінювання. Це розсіяне випромінювання може потрапляти у датчик навіть при хорошій колімації. Тому товщина шару поглинача не повинна перевищувати середню довжину вільного пробігу гальмівного випромінювання (максимальна товщина для $\mathrm{Pb}$ дорівнює 2 см, для $\mathrm{Al}-13,8 \mathrm{~cm})$. 3 метою усунення впливу розсіяних квантів, поглиначі з алюмінію і свинцю були зроблені циліндричної форми товщиною 1,3 cм (вага Al поглинача 770 г, $\mathrm{Pb}-954$ г), які повністю накривають СdTе-датчик (розміром $5 \times 5 \times 2$ мм) з усіх боків (рис. 2). lung (maximum thickness for $\mathrm{Pb}$ is $2 \mathrm{~cm}$, for $\mathrm{Al}-13.8 \mathrm{~cm}$ ). In order to eliminate the influence of scattered quanta, absorbers made of aluminum and lead were made cylindrical with the thickness of $1.3 \mathrm{~cm}$ (the weight of $\mathrm{Al}$ absorber - $770 \mathrm{~g}, \mathrm{~Pb}-954 \mathrm{~g})$, which completely cover the CdTe sensor $(5 \times 5 \times 2 \mathrm{~mm})$ on all sides (Fig. 2).

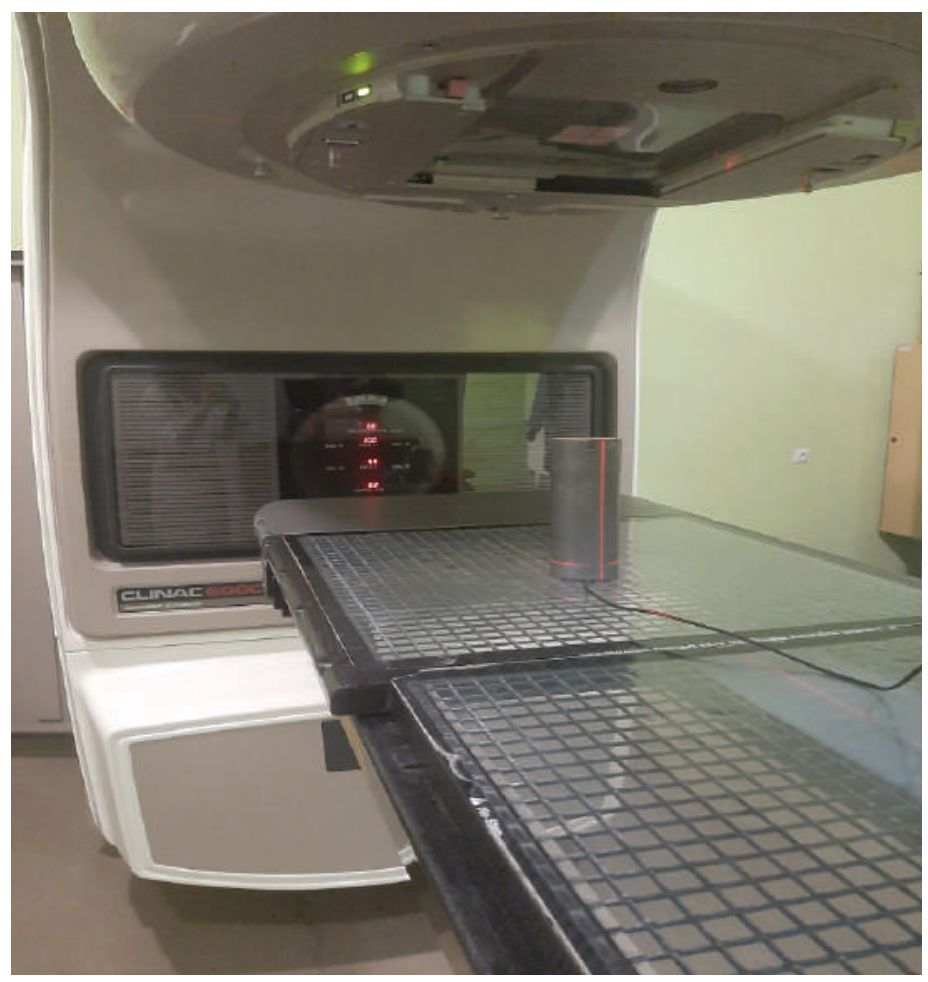

Рис. 2. Геометрія експерименту під час визначення середньої зваженої енергії гальмівного випромінювання лінійного прискорювача (свинцевий поглинач)

Fig. 2. Geometry of the experiment in determining the weighted average braking energy of a linear accelerator (lead absorber)

Датчик було розташовано у поглиначі на відстані одного сантиметру від його поверхні. На відмінність від застосованих у роботі [10] датчиків (збірка сцинтилятор - ФЕП) CdТе-датчик має малі габарити та вагу, широкий динамічний діапазон вимірювальних енергій, більш високий квантовий вихід та надійність роботи. Крім того він має більшу радіаційною стійкість та кращу енергетичну роздільну здатність [17-22]. На відмінність від датчиків на основі сцинтиляторів CdTe-датчик здійснює пряме перетворення енергії гальмівного випромінювання у електричний сигнал з урахуванням енергії фоотонів гальмівного випромінювання.

У експерименті реєстрація середньої зваженої енергії гальмівного випромінювання лінійного прискорювача здійснювалась апаратно-програмним комплексом вимірювання ITM (версія 4.4.1.2) в основі якого є комп'ютерний вимірювальний прилад - електронний блок, який включає чотириканальний 16-розрядний АЦП, мікроконтролер, інтерфейс сполучення з комп'ютером (рис. 3). До електронного блоку через підсилювач під'єднується CdTe-датчик, який працює в імпульсному режимі.

Для точного вимірювання амплітуди окремого імпульсу гальмівного випромінювання був включений
The sensor was located in the absorber at a distance of one centimeter from its surface. Unlike the sensors (scintillator-FEP) used in [10], the CdTe sensor has a small size and weight, a wide dynamic range of measuring energies, a higher quantum yield and reliability. In addition, it has greater radiation resistance and better energy separating power [17-22]. Unlike sensors based scintillators, CdTe sensor directly converts bremsstrahlung energy into an electrical signal, taking into account the energy of bremsstrahlung photons.

In the experiment, the registration of the average measured bremsstrahlung of the linear accelerator was carried out by the hardware-software complex of ITM measurement (version 4.4.1.2) based on a computer measuring device - an electronic unit that includes a fourchannel 16-bit ADC, microcontroller, interface of connection with a computer (Fig. 3). CdTe sensors operating in pulse mode are connected to the electronic unit via intensifier.

A peak detector was included to accurately measure the amplitude of a single bremsstrahlung pulse. In the pulse scheme of involving the CdTe sensor with a peak detector, the rate from bremsstrahlung will be determined by the 


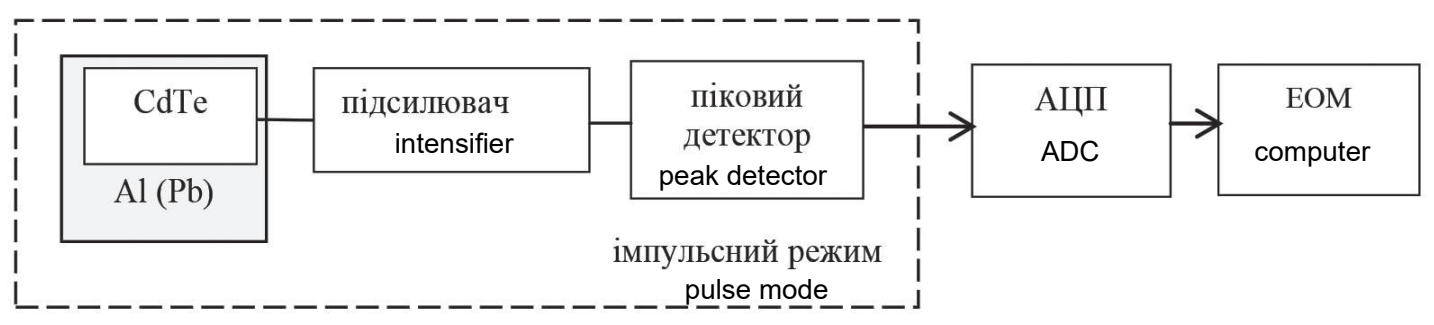

Рис. 3. Функціональна схема діагностичної установки дослідження спектральних характеристик прискорювача

Fig. 3. Functional diagram of the diagnostic installation for the study of the spectral characteristics of the accelerator

піковий детектор. При імпульсній схемі включення CdTe-датчика з піковим детектором швидкість лічби від гальмівного випромінювання буде визначатися амплітудою імпульсу, тоді під час використання $\mathrm{Al}$ та $\mathrm{Pb}$ поглиначів, можливо записати вираз:

$$
A_{m}{ }^{A l} \cdot \mu_{m}^{A l}=A_{m}^{P b} \cdot \mu_{m}^{P b}
$$

де $A_{m}{ }^{A l}\left(A_{m}{ }^{P b}\right)$ - амплітуда імпульсу (у відносних одиницях АЦП) з алюмінієвим поглиначем визначеної

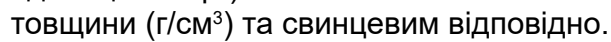

Співвідношення значень $\mu_{m}^{P_{b}} / \mu_{m}^{A l}$ визначалось за відношенням середніх значень амплітуд імпульсів $A_{m}{ }^{A l} / A_{m}{ }^{P b}$ за визначений проміжок часу. Точність визначення середньої зваженої енергії гальмівного випромінювання лінійного прискорювача, залежіть від похибки застосованого 16-розрядного АЦП (0,06\%) та врахування різниці ваги поглиначів $K_{\text {попр }}=\frac{\Gamma_{A l}}{\Gamma_{P b}}=0,807$.

Суть визначення середньої зваженої енергії гальмівного випромінювання лінійного прискорювача полягає у реалізації виразу:

$$
\mu_{m}^{P_{p}} / \mu_{m}^{A l}=\left(A_{m}^{A l} / A_{m}^{P b}\right) \times K_{\text {nonp }}
$$

Таким чином, запропонований підхід полягає у послідовному вимірюванні середньої амплітуди імпульсів з алюмінієвим та свинцевим поглиначем та подальшому порівнянні отриманого співвідношення з існуючою залежністю масових коефіцієнтів ослаблення від енергії випромінювання (табл. 1).

\section{РЕЗУЛЬТАТИ ТА ЇХ ОБГОВОРЕННЯ}

Експериментальна оцінка середньої зваженої енергії гальмівного випромінювання прискорювача проводилась у відділенні радіаційної онкології інституту на лінійному прискорювачі Varian Clinac $600 \mathrm{C}$ на відстані $100 \mathrm{~cm}$ з площею поля $20 \times 20$ см. На рис. 4 та 5 наведені форми імпульсів, зареєстрованих піковим детектором протягом 10 секунд вимірювання запропонованим апаратно-програмним комплексом при 400 моніторних одиницях (потужність дози 4 Гр/хв).

Середнє значення амплітуди склало близько 15777 та 9500 відносних одиниць АЦП з алюмінієвим та зі свинцевим поглиначем відповідно. Відношення масових коефіцієнтів ослаблення - 1,340, що відповідає середній зваженій енергії гальмівного випромінювання у 0,72 МеВ (рис. 6) та відрізняться на $12,5 \%$ від встановленого значення під час введення лінійного прискорювача в експлуатацію.

Шляхом зміни розташування датчика вдовж радіальної осі розповсюдження гальмівного випромінювання у amplitude of the pulse, then when using $\mathrm{Al}$ and $\mathrm{Pb}$ absorbers, it is possible to write the expression:

$$
A_{m}{ }^{A l} \cdot \mu_{m}^{A l}=A_{m}{ }^{P b} \cdot \mu_{m}^{P b}
$$

where $A_{m}{ }^{A l}\left(A_{m}{ }^{P b}\right)$ - pulse amplitude (in relative ADC units) with an aluminum absorber of certain thickness $\left(\mathrm{g} / \mathrm{cm}^{3}\right)$ and lead, respectively.

The ratio of values $\mu_{m}^{P_{0}} / \mu_{m}^{A l}$ was determined by the ratio of the average values of the pulse amplitudes $A_{m}{ }^{A l} / A_{m}{ }^{P b}$ for a certain period of time. The accuracy of determining the average measured energy of bremsstrahlung of the linear accelerator depends on the error of the applied 16-bit ADC $(0.06 \%)$ and the difference in weight of the absorbers $K_{\text {nonp }}=\frac{\Gamma_{A l}}{\Gamma_{P b}}=0,807$.

The essence of determining the average measured energy of bremsstrahlung of the linear accelerator consists in implementing the expression:

$$
\mu_{m}^{P_{b}} / \mu_{m}^{A l}=\left(A_{m}{ }^{A l} / A_{m}{ }^{P b}\right) \times K_{\text {nonp }}
$$

Thus, the suggested approach is to sequentially measure the average pulse amplitude with aluminum and lead absorber and then compare the obtained relationship with the existing dependence of the mass attenuation coefficients on the radiation energy (Table 1).

\section{RESULTS AND DISCUSSION}

Experimental evaluation of the average measured energy of bremsstrahlung of the accelerator was performed by means of the Varian Clinac $600 \mathrm{C}$ linear accelerator (USA) at Radiation Oncology Department of the Institute at a distance of $100 \mathrm{~cm}$ with a field area of $20 \times 20 \mathrm{~cm}$. Figures 4 and 5 show the forms of pulses registered by the peak detector during 10 seconds of measurement by the proposed hardware and software complex at 400 monitor units (dose rate $4 \mathrm{~Gy} / \mathrm{min}$.)

The average amplitude values were about 15777 and 9500 relative units of ADC with aluminum and lead absorber, respectively. The ratio of mass attenuation coefficients was 1.340, which corresponds to the average measured energy of bremsstrahlung of $0.72 \mathrm{MeV}$ (Fig. 6) and differs by $12.5 \%$ from the set value during the commissioning of the linear accelerator.

By changing the location of the sensor along the radial axis of spreading bremsstrahlung within the formed field $(20 \times 20 \mathrm{~cm})$, we obtained the dependence of the average 


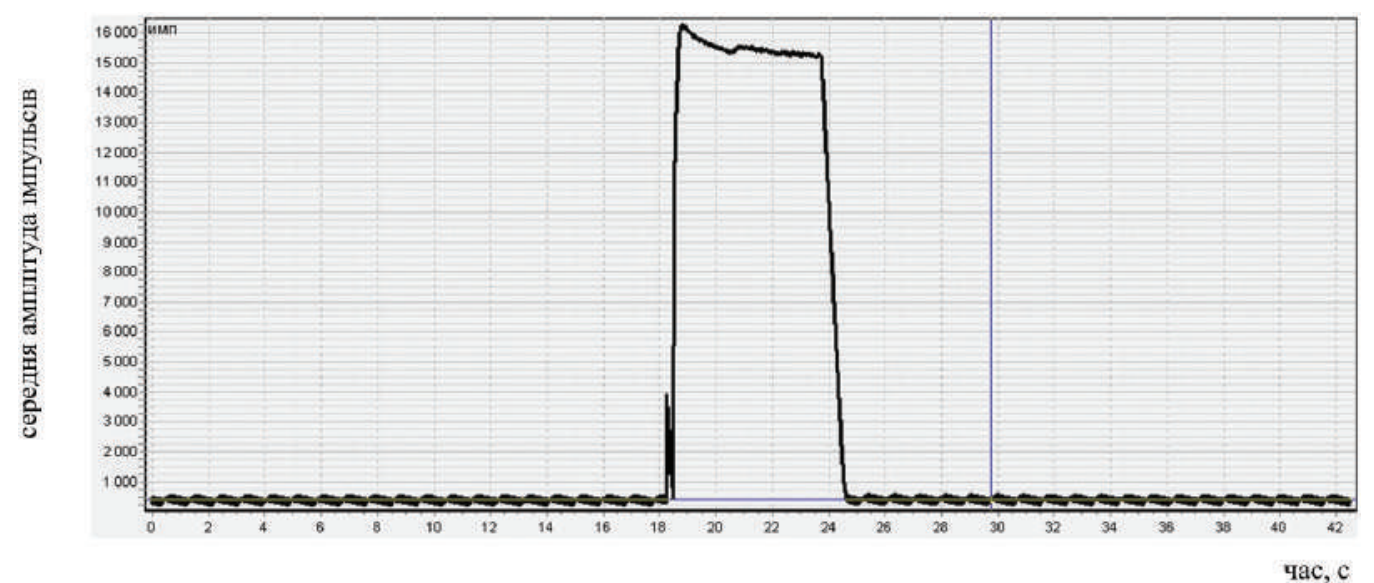

Рис. 4. Середня амплітуда зареєстрованих імпульсів CdTе-датчиком з алюмінієвим поглиначем $\left(\mathrm{A}_{\mathrm{m}}{ }^{\mathrm{Al}}=15777\right.$ відносних одиниць АЦП)

Fig. 4. The average amplitude of the registered CdTe pulses by a sensor with an aluminum absorber $\left(A_{m}{ }^{A l}=15777\right.$ relative units of $\left.A D C\right)$

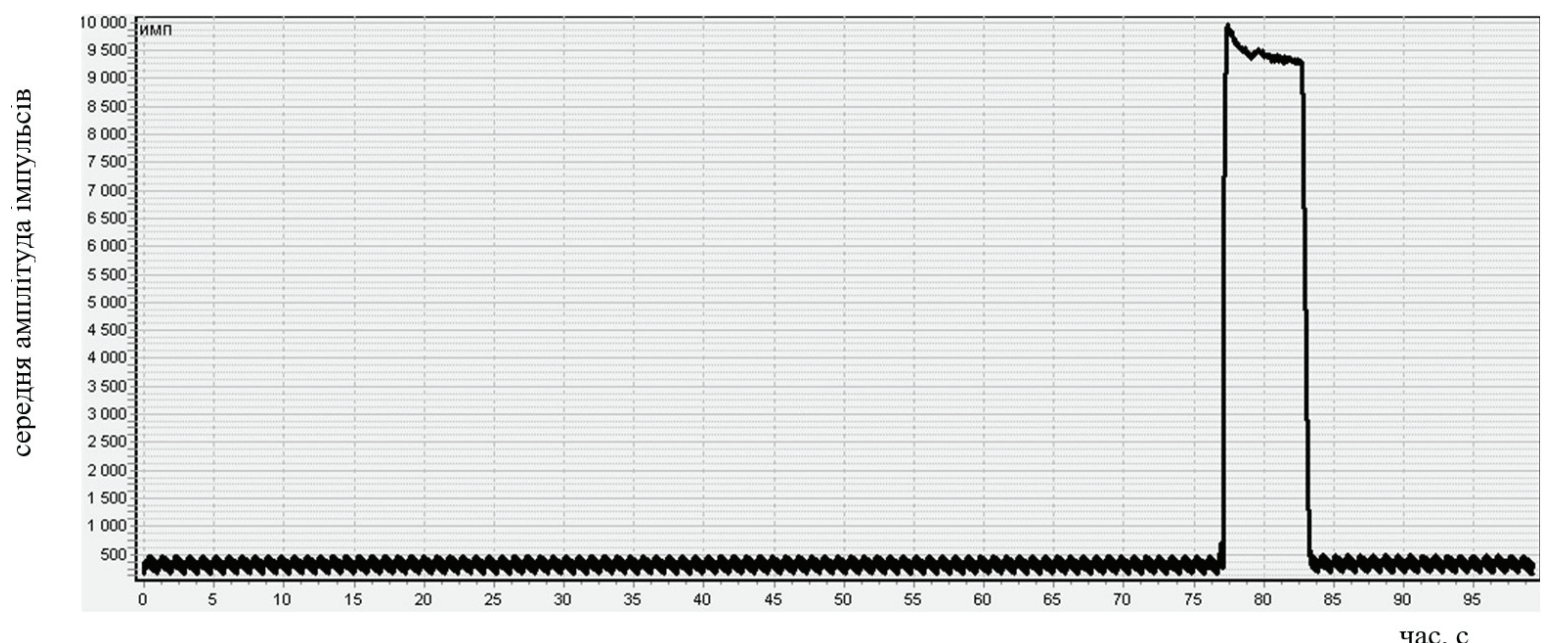

Рис. 5. Середня амплітуда зареєстрованих імпульсів CdTе-датчиком зі свинцевим поглиначем $\left(A_{m}{ }^{\mathrm{Pb}}=9500\right.$ відносних одиниць АЦП)

Fig. 5. The average amplitude of the registered CdTe pulses by the sensor with a lead absorber $\left(A_{m}{ }^{P b}=9500\right.$ relative units of $\left.A D C\right)$

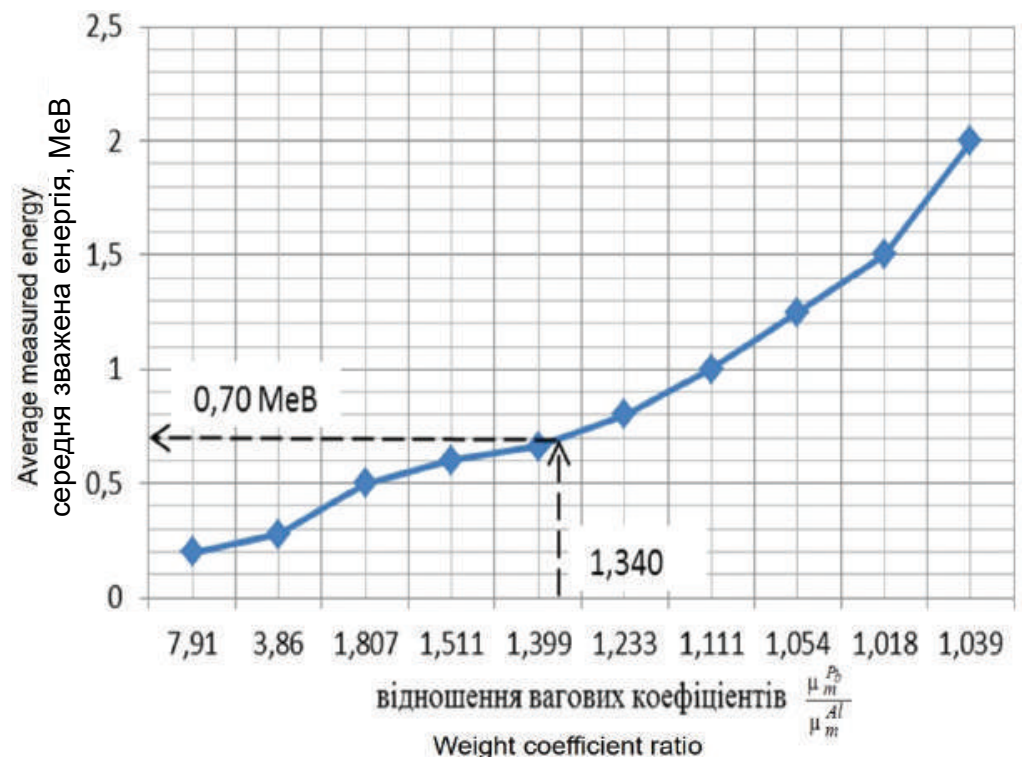

Рис. 6. Залежність середньої зваженої енергії гальмівного випромінювання від відношення масових коефіцієнтів ослаблення

Fig. 6. Dependence of the average weighted energy of bremsstrahlung on the ratio of mass attenuation coefficients 
межах сформованого поля (20 x 20 см) нами отримана залежність середньої зваженої енергії від радіусу (рис. 7). Отриманий важливий параметр, який впливає на енергетичний спектр сформованого поля гальмівного випромінювання лінійного прискорювача - це середня енергія як функція радіусу від центральної осі випромінювання. Дана залежність необхідна для оцінки ефректу «згладжування» спектра гальмівного випромінювання існуючим фрільтром. measured energy on the radius (Fig. 7). The obtained important parameter that affects the energy spectrum of the generated field of bremsstrahlung of the linear accelerator is the average energy as a function of the radius from the central axis of radiation. This dependence is necessary to assess the effect of "smoothing" the spectrum of bremsstrahlung by an existing filter.

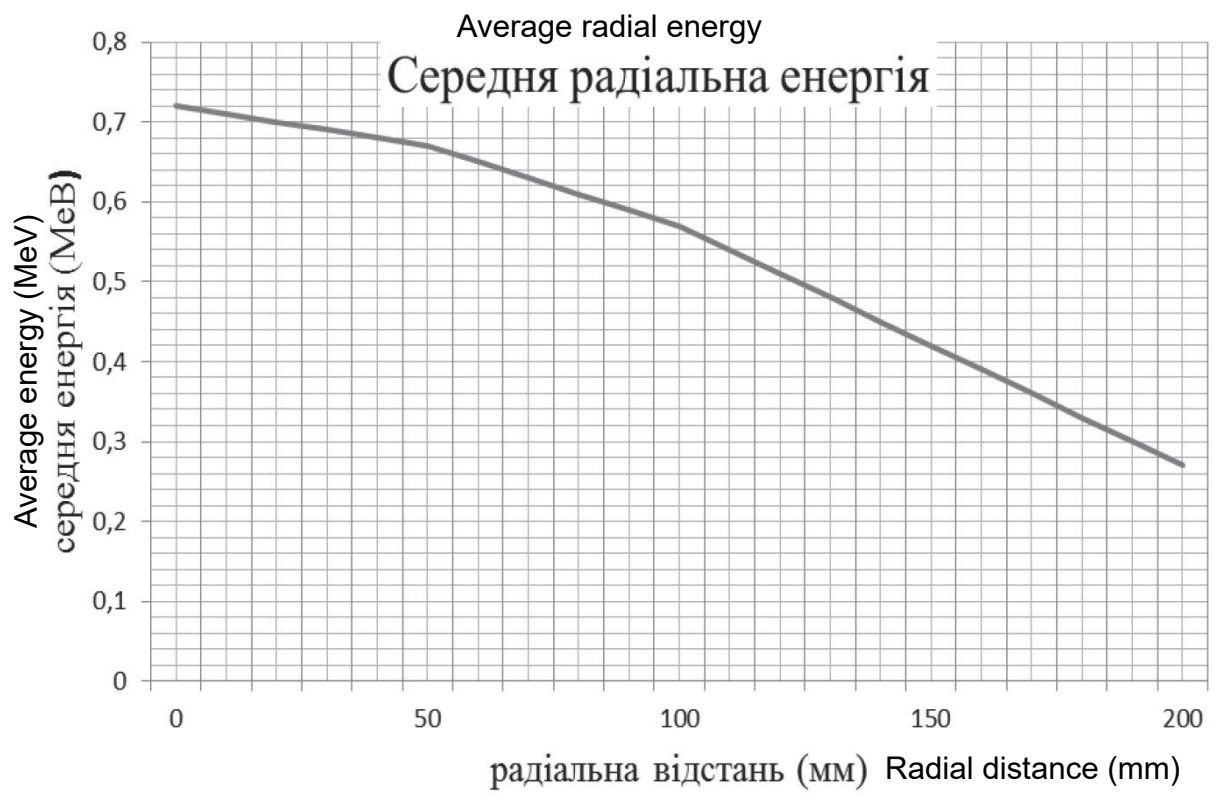

Рис. 7. Залежність середньої зваженої енергії від відстані від центральної осі поля гальмівного випромінювання

Fig.7. Dependence of the average weighted energy on the distance from the central axis of the field of bremsstrahlung

3 метою більш оперативної оцінки спектральних характеристик лінійного прискорювача, враховуючи особливості радіального розподілу (рис. 7), а також існуючі вільні канали АЦП, можливо одночасно використовувати запропоновані циліндричні поглиначі без зменшення точності вимірювання середньої зваженої енергії гальмівного випромінювання.

Таким чином, експериментально підтверджений підхід до оцінки середньої зваженої енергії гальмівного випромінювання лінійного прискорювача, який базується на залежності ослаблення випромінювання шаром поглинача від енергії випромінювання.
In order to more quickly assess the spectrum characteristics of the linear accelerator, taking into account the peculiarities of the radial distribution (Fig. 7), as well as existing free ADC channels, it is possible to use the suggested cylindrical absorbers without reducing the accuracy of measuring the average measured energy of bremsstrahlung.

Thus, the approach to estimate the average measured energy of bremsstrahlung of the linear accelerator, based on the dependence of attenuation of radiation by the absorber layer on the radiation energy, has been experimentally confirmed.

\section{ВИСНОВКИ}

1. Отримана теоретична залежність середньої зваженої енергії гальмівного випромінювання лінійного прискорювача від відношення масових коефіцієнтів ослаблення свинцю та алюмінію. Енергетичному діапазону від 0,1 до 6 МеВ відповідає відношення масових коефіцієнтів ослаблення свинцю до алюмінію яке змінюється нелінійно від 33,8 до 1,639. Для середньої зваженої енергії лінійного прискорювача у 0,8 МеВ відношення масових коефіцієнтів складає близько 1,23 для даних матеріалів.

2. Обґрунтована та практично реалізована спеціальна діагностична апаратура реєстрації спектральних характеристик лінійного прискорювача Varian Clinac 600C (США) на основі напівпровідникових CdTe-датчиків, які сумісно з 16-розрядним АЦП, дозволяють оцінити середню зважену енергію гальмівного випромінювання, шляхом порівняння масових

\section{CONCLUSIONS}

1. The theoretical dependence of the average measured energy of bremsstrahlung of the linear accelerator on the ratio of the mass attenuation coefficients of lead and aluminum has been obtained. The energy range from 0.1 to $6 \mathrm{MeV}$ corresponds to the ratio of the mass attenuation coefficients of lead to aluminum, which varies nonlinearly from 33.8 to 1.639 . For average measured energy of the linear accelerator of $0.8 \mathrm{MeV}$, the ratio of mass coefficients is about 1.23 for these materials.

2. The special diagnostic equipment for recording the spectrum characteristics of the Varian Clinac 600C linear accelerator (USA) based on semiconductor CdTe sensors, which along with 16-bit ADC make it possible to estimate the average measured energy of bremsstrahlung via comparing mass attenuation coefficients in $\mathrm{Al}$ and $\mathrm{Pb}$, has been substantiated and reduced to practice. The assessment of mass attenuation coefficients is carried out 
коефіцієнтів ослаблення у $\mathrm{Al}$ та $\mathrm{Pb}$. Оцінка масових коефіцієнтів ослаблення здійснюється на основі вимірювання середніх амплітуд імпульсів CdTe-датчиків, працюючих у імпульсному режимі. Аналіз показав, що істотним джерелом похибок при визначенні середньої зваженої енергії гальмівного випромінювання може стати недостатньо хороша «геометрія» експерименту, при якому у датчик може потрапляти частина розсіяного випромінювання. Для зменшення м'якого розсіяного випромінювання поглиначі з алюмінію і свинцю були зроблені циліндричної фрорми.

3. Абсолютна похибка (відносно встановленого значення під час введення В експлуатацію лінійного прискорювача) визначеної середньої зваженої енергії гальмівного випромінювання не перевищує 12,5\% $(0,72 \mathrm{MeB})$, що відповідає відношенню масових коефіцієнтів ослаблення - 1,340.

4. Аналіз отриманої залежності розподілу середньої зваженої енергії вдовж центральної осі поля гальмівного випромінювання дає можливість оцінювати ефект «згладжування» спектра гальмівного випромінювання існуючим фрільтром та одночасно використовувати запропоновані циліндричні поглиначі без зменшення точності вимірювання середньої зваженої енергії гальмівного випромінювання. Це відкриває широкі можливості застосування CdTе-датчиків для створення діагностичних систем лінійного прискорювача медичного призначення. based on measurement of average amplitudes of pulses of CdTe of the sensors operating in a pulse mode. The analysis has shown that a significant source of errors in determining the average measured energy of bremsstrahlung can be the experiment "geometry» which is not quite good, in which the sensor can get part of the scattered radiation. Aluminum and lead absorbers were made in a cylindrical shape to reduce soft scattered radiation.

3. The absolute error (towards the set value during the commissioning of the linear accelerator) of the specified average measured energy of bremsstrahlung is up to $12.5 \%(0.72 \mathrm{MeV})$, corresponding to the ratio of mass attenuation coefficients -1.340 .

4. The analysis of the obtained dependence of the average measured energy distribution along the central axis of the bremsstrahlung field makes it possible to assess the effect of "smoothing» the bremsstrahlung spectrum by the existing filter and simultaneously use the suggested cylindrical absorbers without reducing the accuracy of measuring the average bremsstrahlung energy. This offers the potential for the use of CDTe sensors to create diagnostic systems for linear accelerators for medical purposes.

\section{СПИСОК ВИКОРИСТАНОÏ ЛІТЕРАТУРИ}

1. Титович Е. В., Тарутин И. Г., Киселев М. Г. Методика определения ошибки в опорном значении дозы при калибровке радиационного выхода линейного ускорителя. Приборы и методы измерений. 2016. T. 7, № 2. C. 203-210. DOI: https://doi.org/10.21122/2220-95062016-7-2-203-210

2. Lye J. E., Butler D. J., Ramanathan G., Franich R. D. Spectral differences in $6 \mathrm{MV}$ beams with matched PDDs and the effect on chamber response. Physics in medicine and biology. 2012. Vol. 21,57(22). P. 7599-7614. DOI: https://doi.org/10.1088/0031-9155/57/22/7599

3. Jeraj R., Mackie T. R., Balog J., Olivera G., Pearson D., Kapatoes J., Ruchala K., Reckwerdt P. Radiation characteristics of helical tomotherapy. Medical physics. 2004. Vol. 31(2). P. 396-404. DOI: https:// doi.org/10.1118/1.1639148. PMID: 15000626

4. Determination of absorbed dose in a patient irradiated by beams of $x-$ or gamma-rays in radiotherapy procedures. ICRU. 1976. Report 24.

5. Старенький В. П., Авер'янова Л. О. Апарати дистанційної променевої терапії. Планета-Прінт. 2015. 160 с. URL: http://openarchive. nure.ua/handle/document/2514

6. International atomic energy agency. Design and Implementation of a Radiotherapy Programme: Clinical, Medical Physics, Radiation Protection and Safety Aspects, IAEA-TECDOC-1040. IAEA. Vienna. 1998. URL: https://www.iaea.org/publications/5337/design-andimplementation-of-a-radiotherapy-programme-clinical-medicalphysics-radiation-protection-and-safety-aspects

7. Kutcher G. J., Coia L., Gillin M., Hanson W. F., Leibel S. et al. Comprehensive QA for radiation oncology: report of AAPM Radiation Therapy Committee Task Group 40. Medical physics. 1994. Vol. 21(4). P. 581-618. DOI: https://doi.org/10.1118/1.597316. PMID: 8058027

8. Taneja S., Bartol L. J., Culberson W., De Werd L. A. Measurement of the Energy Spectrum of a $6 \mathrm{MV}$ Linear Accelerator Using Compton Scattering Spectroscopy and Monte Carlo-Generated Corrections. International Journal of Medical Physics, Clinical Engineering and Radiation Oncology. 2020. Vol. 9. P. 186-200. DOI: https://doi.org/ 10.4236/ijmpcero.2020.94017

9. Миронов Н. К., Лазарев С. А., Грунин А. В., Залялов А. Н. Измерение средней энергии квантов тормозного излучения ускорителя ЛИУ-30 методом детекторов с линейными спектральными характеристиками. Труды РФЯЦ-ВНИИЭФ. 2010. Вып. 15. С. 332-338.

10. Миронов Н. К. Метод измерения средней энергии квантов тормозного излучения ускорителя ЛИУ-30. Труды РФЯЦ-ВНИИЭФ. 2015. № 20(1) C. 161-172. URL: https://rucont.ru/efd/556569

11. Герасимов А. И., Гордеев В. С., Горностай-Польский С. А. и др. Измерение характеристик высокоинтенсивных полей излучений при проведении радиационных исследований на моделирующих

\section{REFERENCES}

1. Titovich EV, Tarutin IG, Kiselev MG. Method for determining the erro in the reference dose value when calibrating the radiation output of a linear accelerator. Instruments and methods of measurement. 2016;7(2):203-10. (In Russian). DOI: https://doi.org/10.21122/22209506-2016-7-2-203-210

2. Lye JE, Butler DJ, Ramanathan G, Franich RD. Spectral differences in $6 \mathrm{MV}$ beams with matched PDDs and the effect on chamber response. Physics in medicine and biology. 2012;21,57(22):7599-614. (In English). DOI: https://doi.org/10.1088/0031-9155/57/22/7599

3. Jeraj R, Mackie TR, Balog J, Olivera G, Pearson D, Kapatoes J, Ruchala K, Reckwerdt P. Radiation characteristics of helical tomotherapy. Medical physics. 2004;31(2):396-404. (In English) DOI: https://doi.org/10.1118/1.1639148. PMID: 15000626

4. Determination of absorbed dose in a patient irradiated by beams of $x$ or gamma-rays in radiotherapy procedures. ICRU. 1976;24. (In English).

5. Starenky VP, Averyanova LO. Devices of remote radiation therapy. Planet Print. 2015;160. (In Ukrainian). URL: http://openarchive.nure.ua/ handle/document/2514

6. International atomic energy agency. Design and Implementation of a Radiotherapy Programme: Clinical, Medical Physics, Radiation Protection and Safety Aspects, IAEA-TECDOC-1040. IAEA. Vienna. 1998. (In English). URL: https://www.iaea.org/publications/5337/ design-and-implementation-of-a-radiotherapy-programme-clinicalmedical-physics-radiation-protection-and-safety-aspects

7. Kutcher GJ, Coia L, Gillin M, Hanson WF, Leibel Setal. Comprehensive QA for radiation oncology: report of AAPM Radiation Therapy Committee Task Group 40. Medical physics. 1994;21(4):581-618. (In English). DOI: https://doi.org/10.1118/1.597316. PMID: 8058027

8. Taneja S, Bartol LJ, Culberson W, De Werd LA. Measurement of the Energy Spectrum of a $6 \mathrm{MV}$ Linear Accelerator Using Compton Scattering Spectroscopy and Monte Carlo-Generated Corrections. International Journal of Medical Physics, Clinical Engineering and Radiation Oncology. 2020;9:186-200. (In English). DOI: https://doi.org/ 10.4236/ijmpcero.2020.94017

9. Mironov NK, Lazarev SA, Grunin AV, Zalyalov AN. Measurement of the average energy of the bremsstrahlung quanta of the LIU-30 accelerator by the method of detectors with linear spectral characteristics. Proceedings of RFNC-VNIIEF. 2010;15:332-8. (In Russian).

10. Mironov NK. Method for measuring the average energy of the bremsstrahlung quanta of the LIU-30 accelerator. Proceedings of RFNC-VNIIEF. 2015;20(1):161-72. (In Russian). URL: https://rucont.ru/ efd/556569

11. Gerasimov Al, Gordeev VS, Gornostay-Polsky SA et al. Measurement of characteristics of high-intensity radiation fields during radiation 
установках и комплексах. РФЯЦ-ВНИИЭФ. Приборы и теника эксперемента. 2006. С. 73-80.

12. Одинцов Ю. М., Крыжановский А. А., Маслов Г. Н., Кошелев А. С. и др. Определение спектра тормозного излучения ускорителя ЛИУ-30 активационным методом. Физика ядерних реакторов. 1999. Вып. 3-4. С. 35-42.

13. Овчинникова Л. Ю., Шведунов В. И. Влияние энергетического спектра пучка электронов на оценку его энергии методом ослабления тормозного излучения поглощающим барьером. Ученые записки ффизического фракультета московского университета. 2018. № 1. C. 1-4.

14. Немец О. Ф., Гофмман Ю. В. Справочник по ядерной фризике. Киев. Наукова думка. 1975

15. Choi H. J., Park H., Yi C. Y., Kim B-C. et al. Determining the energy spectrum of clinical linear accelerator using an optimized photon beam transmission protocol. International Journal of Medical Physics Research and Practise. 2019. Vol. 46(7). P. 3285-3297. DOI: https:// doi.org/10.1002/mp.13569

16. Takagi H., Murata I. Energy Spectrum Measurement of High Power and High Energy (6 and $9 \mathrm{MeV}$ ) Pulsed X-ray Source for Industrial Use. Journal of Radiation Protection and Reseasrch. 2016. Vol. 41(2). P. 93-99. DOI: https://doi.org/10.14407/jrpr.2016.41.2.093

17. Чернявский И. Ю., Тютюник В. В., Калугин В. Д., Пудло И. В. Использование методов дозиметрии ионизирующих излучений для оценки воздействия на живые организмы низкоэнергетического гамма-излучения на радиоактивно зараженной локальной территории в рамках проведения радиационного мониторинга в Украине. Харківський національний університет Повітряних Сил ім. Івана Кожедуба. 2017. Вип. 3(149). С. 169-179.

18. Rybka A. V., Davydov L. N., Shlyakhov I. N., Kutny V. E., Prokhoretz I. M. Kutny D. V., Orobinsky A. N. Gamma-radiation dosimetry with semiconductor CdTe and CdZnTe detectors. Nuclear Instruments and Methods in Physics Research Section A: Accelerators, Spectrometers Detectors and Associated Equipment. 2004. Vol. 531(1-2). P. 147-156. DOI: https://doi.org/10.1016/j.nima.2004.05.107

19. Berger M., Hubbell J., Seltzer S. et al. XCOM: Photon cross sections database. NIST Standard Reference Database 8 (XGAM). URL:http:// physics.nist.gov/PhysRefData/Xcom/Text/XCOM.html

20. Эльяш С. Л., Родигин А. В., Лойко Т. В., Поляков А. И., Капитанов С. В. $\mathrm{CdTe}$ детекторы для регистрации импульсов рентгеновского излучения с субнаносекундным разрешением. ПТЭ. 2011. № 4. С. 86-88.

21. Scheiber C. CdTe and CdZnTe detectors in nuclear medicine. Nuclea Instruments and Methods in Physics Research Section A: Accelerators, Spectrometers, Detectors and Associated Equipment. 2000. Vol. 448(3) P. 513-524. DOI: https://doi.org/10.1016/S0168-9002(00)00282-5.

22. Scheiber C., CGiakos G. Medical applications of CdTe and CdZnTe detectors. Nuclear Instruments and Methods in Physics Research Section A: Accelerators, Spectrometers, Detectors and Associated Equipment. 2001.Vol. 458(1-2). P. 12-25. DOI: https://doi.org/10.1016/ S0168-9002(00)01032-9

23. Nagarkar V., Squillante M., Entine G., Stern I., Sharif D. CdTe detectors in nuclear radiation dosimetry. Nuclear Instruments and Methods in Physics Research Section A: Accelerators, Spectrometers, Detectors and Associated Equipment. 1992. Vol. 322(3). P. 623-627. DOI: https:// doi.org/10.1016/0168-9002(92)91242-2 research on simulating installations and complexes. RFNC-VNIIEF. Instruments and shades of experiment. 2006;73-80. (In Russian).

12. Odintsov YuM, Kryzhanovskiy AA, Maslov GN, Koshelev AS et al. Determination of the bremsstrahlung spectrum of the LIU-30 accelerator by the activation method. Physics of nuclear reactors. 1999;3-4:35-42. (In Russian).

13. Ovchinnikova LYu, Shvedunov VI. Influence of the energy spectrum of an electron beam on the estimation of its energy by the method of attenuation of bremsstrahlung by an absorbing barrier. Scientific Notes of the Physics Faculty of Moscow University. 2018;1:1-4. (In Russian).

14. Nemets OF, Hoffman YuV. Nuclear Physics Handbook. Kiev. Naukova dumka. 1975. (In Russian).

15. Choi HJ, Park H, Yi CY, Kim B-C et al. Determining the energy spectrum of clinical linear accelerator using an optimized photon beam transmission protocol. International Journal of Medical Physics Research and Practise. 2019;46(7):3285-97. (In English). DOI: https:// doi.org/10.1002/mp.13569

16. Takagi H, Murata I. Energy Spectrum Measurement of High Power and High Energy (6 and $9 \mathrm{MeV}$ ) Pulsed X-ray Source for Industrial Use. Journal of Radiation Protection and Reseasrch. 2016;41(2):93-9. (In English). DOI: https://doi.org/10.14407/jrpr.2016.41.2.093

17. Chernyavsky IYu, Tyutyunik VV, Kalugin VD, Pudlo IV. Using ionizing radiation dosimetry methods to assess the impact of low-energy gamma radiation on living organisms in a radioactively contaminated local area within the framework of radiation monitoring in Ukraine. Kharkiv National University of the Powers of the Im. Ivana Kozheduba. 2017;3(149):169-79. (In Russian).

18. Rybka AV, Davydov LN, Shlyakhov IN, Kutny VE, Prokhoretz IM, Kutny DV, Orobinsky AN. Gamma-radiation dosimetry with semiconductor CdTe and CdZnTe detectors. Nuclear Instruments and Methods in Physics Research Section A: Accelerators, Spectrometers, Detectors and Associated Equipment. 2004;531(1-2):147-56. (In English). DOI: https://doi.org/10.1016/j.nima.2004.05.107

19. Berger M, Hubbell J, Seltzer $S$ et al XCOM: Photon cross sections database. NIST Standard Reference Database 8 (XGAM). (In English). URL:http://physics.nist.gov/PhysRefData/Xcom/Text/XCOM.html

20. Elyash SL, Rodigin AV, Loiko TV, Polyakov AI, Kapitanov SV. CdTe detectors for recording $X$-ray pulses with subnanosecond resolution. PTE. 2011;4:86-8. (In Russian).

21. Scheiber C. CdTe and CdZnTe detectors in nuclear medicine. Nuclear Instruments and Methods in Physics Research Section A: Accelerators, Spectrometers, Detectors and Associated Equipment. 2000;448(3):513-24. (In English). DOI: https://doi.org/10.1016/S01689002(00)00282-5

22. Scheiber C, CGiakos G. Medical applications of CdTe and CdZnTe detectors. Nuclear Instruments and Methods in Physics Research Section A: Accelerators, Spectrometers, Detectors and Associated Equipment. 2001;458(1-2):12-25. (In English). DOI: https://doi.org/ 10.1016/S0168-9002(00)01032-9

23. Nagarkar V, Squillante M, Entine G, Stern I, Sharif D. CdTe detectors in nuclear radiation dosimetry. Nuclear Instruments and Methods in Physics Research Section A: Accelerators, Spectrometers, Detectors and Associated Equipment. 1992;322(3):623-7. (In English). DOI: https://doi.org/10.1016/0168-9002(92)91242-2
Перспективи подальших досліджень полягають у вдосконаленні апаратної частини діагностичного комплексу шляхом задіяння всіх чотирьох каналів АЦП. У можливості комплексу виявляти відсотковий внесок різних діапазонів енергій гальмівного випромінювання медичного прискорювача за допомогою різних рівнів дискримінації АЦП.
Prospects for further research consist in improving the hardware of the diagnostic complex by using all four ADC channels. The complex is able to detect the percentage contribution of different ranges of bremsstrahlung energies of the medical accelerator by means of different levels of ADC discrimination.
Чернявський Ігор Юрійович - кандидат технічних наук, доцент, старший науковий співробітник відділення радіаційної онкології Державної установи «Інститут медичної радіології та
Cherniavskiy Igor Yurievich - Candidate of Technical Sciences, Associate Professor, Senior Researcher of Radiation Oncology Department of State Organization «Grigoriev Institute 
онкології ім. С.П. Григор'єва Національної академії медичних наук України»; вул. Пушкінська, буд. 82, м. Харків, Україна, 61024; e-mail: chern.igor.71@gmail.com моб.: +38 (063) 247-20-43

Внесок автора: формування ідеї та мети дослідження, проведення дослідження, обробка та узагальнення результатів дослідження, наукове редагування статmi.

Старенький Віктор Петрович - доктор медичних наук, професор, завідувач відділення радіаційної онкології Державної установи «Інститут медичної радіології та онкології ім. С.П. Григор'єва Національної академії медичних наук України»; вул. Пушкінська, буд. 82, м. Харків, Україна, 61024; e-mail: starenkiy.victor@gmail.com моб.: +38 (067) 578-21-47

Внесок автора: загальне керівництво проведенням дослідження.

Макієнко Алла Сергіївна - інженер-фізик відділення радіаційної онкології Державної установи «Інститут медичної радіології та онкології ім. С.П. Григор'єва Національної академії медичних наук України»; вул. Пушкінська, буд. 82, м. Харків, Україна, 61024; викладач фрізики Харківського радіотехнічного коледжу Міністерства освіти і науки України; вул. Сумська, буд. 18/20, м. Харків, Україна, 61166;

e-mail: makienko.alla@gmail.com

моб.: +38 (063) 105-20-15

Внесок автора: проведення дослідження, підготовка статmі до друку.

Авер'янова Лілія Олександрівна - доцент кафедри біомедичної інженерії Харківського національного університету радіоелектроніки Міністерства освіти і науки України; просп. Науки, буд. 14, м. Харків, Україна, 61166;

e-mail: lilya.averyanova@nure.ua

моб.: +38 (067) 570-63-39

Внесок автора: проведення дослідження, підготовка статmі до друку.

Петриченко Олександр Олександрович - доктор медичних наук, заступник начальника лікувальноорганізаційного управління президії Національної академії наук України, старший науковий співробітник Національної академії медичних наук України; вул. Юрія Іллєнка, буд. 53, м. Київ, Україна, 04050;

e-mail: medlu@ukr.net

моб.: +38(095) 575-51-46

Внесок автора: організаційні питання дослідження.

Поплавець Сергій Іванович - доктор фрілософії, доцент кафедри тактики та загальновійськових дисциплін Харківського національного університету Повітряних Сил імені Івана Кожедуба Міністерства оборони України; вул. Сумська, буд. 77/79, м. Харків, Україна, 61023;

e-mail: serg751505@gmail.com

моб.: + 38 (098) 832-71-89

Внесок автора: організаційні питання дослідження. for Medical Radiology and Oncology of the National Academy of Medical Sciences of Ukraine»; 82, Pushkinska Str., Kharkiv, Ukraine, 61024;

e-mail: chern.igor.71@gmail.com

ph: +38 (063) 247-20-43

Author's contribution: forming the idea and purpose of the study, conducting the study, processing and summarizing the results, scientific editing of the article.

Starenkyi Viktor Petrovich - Doctor of Medical Sciences, Professor, Head of Radiation Oncology Department of State Organization «Grigoriev Institute for Medical Radiology and Oncology of the National Academy of Medical Sciences of Ukraine»; 82, Pushkinska Str., Kharkiv, Ukraine, 61024;

e-mail: starenkiy.victor@gmail.com

ph: +38 (067) 578-21-47

Author's contribution: general management of the study.

Makienko Alla Serhiivna - Engineering physicist of Radiation Oncology Department of State Organization «Grigoriev Institute for Medical Radiology and Oncology of the National Academy of Medical Sciences of Ukraine»; 82, Pushkinska Str., Kharkiv, Ukraine, 61024; Physics instructor of Kharkiv RadioEngineering College of the Ministry of Education and Science of Ukraine; 18/20, Sumska Str., Kharkiv, Ukraine, 61166;

e-mail: makienko.alla@gmail.com

ph: +38 (063) 105-20-15

Author's contribution: conducting the study, preparing the article for publication.

Averyanova Lilia Oleksandrivna - Associate Professor of Biomedical Engineering Department Kharkiv National University of Radio Electronics of the Ministry of Education and Science of Ukraine; 14, Nauky Ave., Kharkiv, Ukraine, 61166; e-mail: lilya.averyanova@nure.ua

ph: +38 (067) 570-63-39

Author's contribution: conducting the study, preparing the article for publication.

Petrychenko Oleksandr Oleksandrovych - Doctor of Medical Sciences, Deputy Head of Medical and Organizational Department of the Presidium of the National Academy of Sciences of Ukraine, Senior Research Fellow of the National Academy of Medical Sciences of Ukraine; 53, Yuri Ilyenko Str., Kyiv, Ukraine, 04050;

e-mail: medlu@ukr.net

ph: + 38 (095) 575-51-46

Author's contribution: organizational issues of the study.

Poplavetz Serhii Ivanovych - Doctor of Philosophy, Associate Professor of Tactics and General Military Disciplines Ivan Kozhedub Kharkiv National University of the Air Force of the Ministry of Defense of Ukraine; 77/79, Sumska Str., Kharkiv, Ukraine, 61023;

e-mail: serg751505@gmail.com

ph: + 38 (098) 832-71-89

Author's contribution: organizational issues of the study.

\begin{tabular}{|c|c|c|c|}
\hline $\begin{array}{c}\text { Рукопис надійшов } \\
\text { Manuscript was received } \\
\text { 09.07.2021 }\end{array}$ & $\begin{array}{c}\text { Отримано після рецензування } \\
\text { Received after review } \\
25.08 .2021\end{array}$ & $\begin{array}{c}\text { Прийнято до друку } \\
\text { Accepted for printing } \\
\text { 07.09.2021 }\end{array}$ & $\begin{array}{c}\text { Опубліковано } \\
\text { Published } \\
29.09 .2021\end{array}$ \\
\hline
\end{tabular}

